\title{
The Effect of EFL Teachers' Training in Rural West China: Evidence From Phonics-oriented Program
}

\author{
Yeqin Kang ${ }^{1} \&$ Lijuan Liang ${ }^{1}$ \\ ${ }^{1}$ School of English and Education, Guangdong University of Foreign Studies, Guangzhou, China \\ Correspondence: Lijuan Liang, School of English and Education, Guangdong University of Foreign Studies, \\ Guangzhou, 510006, China. E-mail: lianglijuan@oamail.gdufs.edu.cn
}

Received: November 2, 2017

Accepted: February 11, 2018 Online Published: February 13, 2018

doi: $10.5539 /$ elt.v11n3p40

URL: http://doi.org/10.5539/elt.v11n3p40

\begin{abstract}
China has launched a nation-wide project of learning English as a "core" subject starting from the third grade in primary schools after the Ministry of Education (MOE) issued National English Curriculum Standards for Compulsory Education at the beginning of this century. However, EFL teachers are far from sufficient in rural schools, and thus students are in a more disadvantageous position compared to their peers in the urban area. To meet this need, many Zhuangang teachers are employed after being trained. This study examined a phonics-oriented training program in which scholars and practitioners cooperated to train EFL teachers and prospective trainers in rural west China. The current study collected data about EFL teachers' perceptions on the effect of this program and student achievement. The results showed that the training program was quite effective with EFL teachers regarding the program as helpful and students obtaining significantly better scores. These findings indicate that phonics-oriented professional support system is a good way to make teacher development sustainable in the long run.
\end{abstract}

Keywords: EFL teachers' training, trainers' training, phonics, professional support

\section{Introduction}

China has attached great importance to English learning (English as a Foreign Language, EFL) in compulsory education since the beginning of 21 century in response to the rapid development of economy, education, information technology and international communication. As a result, the number of pupils learning English at school soared from 7,000,000 in 1999 (Zheng, 2006) to 90,000,000 in 2005 (Huang \& Chen, 2009) after the issue of National English Curriculum Standards for Compulsory Education in which Year 3 pupils (age 8-9) are required to start learning English (MOE, 2001). However, the scarcity of EFL teachers was a big barrier to the implementation of this policy, particularly in underdeveloped rural areas. Statistics from MOE showed that there were 316,791 rural primary schools in China in 2005, resulting in 2,226,267 classes in rural areas (MOE, 2005). So the number of EFL teachers' shortage in rural schools was huge. To solve this problem, MOE suggested training primary teachers who might be teaching other subjects like Maths or Chinese language yet had already built a relatively good foundation of English language to become English teachers (MOE, 2001). This is called Zhuangang, a new concept in China indicating the change of teaching position. These English teachers are known as Zhuangang English teachers. Encouraged by this guidance, training and research on Zhuangang teachers, a special product of leapfrog development in primary English teaching (Tan, 2011), became a hot issue.

\subsection{Zhuangang English Teachers in China}

Zhuangang English teachers in this study refers to this particular group of EFL teachers, specifically those in-service primary school teachers who teach English yet haven't got a diploma in English language teaching or received systematic English language training in the Chinese context (Lin, 2003). Most of them share these features: three-year English learning experience; not being exposed to English for about ten years; defective pronunciation; fogyish teaching principles and methods (Kang, 2012).

Now lots of Zhuangang English teachers teach in primary schools, especially rural schools. Tan (2011) states that even in economically developed Guangdong province, the proportion of Zhuangang teachers is $65.80 \%$ in the six sample regions. In You's study (2016), rural zhuangang EFL teachers account for $32.5 \%$ in the sample Heyuan city in Guangdong province. Xiong and Xiong's study (2017) shows that $1 / 3$ of the total number in 
Kaiping County is Zhuangang English teachers. Therefore, research on this group of people is significant and meaningful to English teaching and learning.

In the small quantity of published papers sorted out from CNKI (China National Knowledge Infrastructure), most pointed out the significant deficiency of Zhuangang teachers' pronunciation and intonation, and their poor teaching skills before training (Lin, 2003; Zhang, 2004; Xie, 2007; Liu, 2008; You, 2016). Therefore, the training programs in these previous studies covered phonetics and teaching skills (Lin, 2003; Zhang, 2004; Xie, 2007; Liu, 2008; You, 2016). However, in these training programs, phonetics was only part of the training (not the core) with International Phonetic Alphabet (IPA), a system where each symbol is associated with a particular English sound. Phonics was not mentioned in any of these training programs. As is known to all, English teachers' pronunciation is the greatest barrier for pupils' high-quality language input. Therefore, how to equip EFL teachers with more standard pronunciation and thereafter teach children more standard English is a key issue that challenges researchers in this field.

\subsection{Phonics Instruction in China}

Phonics is a way of teaching reading and spelling that stresses symbol-sound relationships. It is used especially in beginning instruction (Harris \& Hodges, 1995). Phonics instruction has been popular since 1990s in many western countries to teach younger children phonetics and reading in schools, and has a great effect on the development of their reading and writing ability. In China, before phonics was introduced, IPA was more commonly used for students to learn English phonetics. They usually learn the names of 26 letters first, and then start to learn IPA which they use to pronounce each word. Take the word "city [siti]" for an example. To pronounce this word, the students first pronounce each sound: [s],[i],[t],[i], then put them together to sound out [siti]; to memorize this word, they write or repeat each letter (c-i-t-y) orally for many times, without being aware of letter-sound correspondences. IPA plays an important role in defining the sound of each word, but causes a serious problem of separating sounds from their correspondent spelling, setting a man-made obstacle in learning English (Chen \& Fan, 2011). Moreover, as an abstract system, IPA is more easily confused with English letters since they look similar, but may have different sounds. Therefore, English teaching in China is in low efficiency, especially in oral English.

As more Chinese pupils start to learn English with the implementation of new national curriculum, it is urgent for researchers to explore more effective English language teaching methods. Against this background, phonics, which has a long history of being used to teach English beginners in North America, emerged in China as a new method to learn phonetics. Through learning phonograms directly, students can develop the skills of "reading the word when seeing it, and writing the word when hearing it" (Gao, 2005). However, no training or research has been conducted yet to explore the effect of phonics on adult schoolteachers.

\subsection{The Current Study}

Taken together, the current study aimed to explore whether more qualified EFL teachers could be produced through a phonic-oriented training program. Funded by Ford Foundation, an American non-profit organization devoted to the improvement of social justice and human achievement, this program provided training for rural Zhuangang teachers from poverty-stricken counties in Ningxia Hui Autonomous Region where EFL teachers were in urgent demand. The current training program was designed to include two subprograms: Training-of-teachers and Training-of-trainers, with the construction of a professional support system.

\subsubsection{Phonics-Oriented Training-of-teachers Program}

In the four-month training program, five sections were covered: phonics as the core, Oral English skills, English teaching skills, English teaching principles, and English textbook teaching. More specifically, 26 single phonograms (names and sounds of 26 letters in Table 1, He, 2008), eight types of multiple phonograms (see Table 2, He, 2008) and phonics spelling rules (See Table 3, Qiang \& Xu, 2006) were taught as core knowledge. Although English sounds have certain rules, but only $50 \%$ of vocabulary has completely transparent sound-form relationship. For example, in cat and nice, letter $c$ has different sounds. The former sounds [k], the letter-sound of $c$, while the latter sounds [s]. How can the learner judge whether $c$ is pronounced [k] or [s]? This rule may be helpful: when letter $c$ comes with $a, o$ or $u$ after it, it has the sound of [k], like in the example words: cat, cot, cut; when $c$ comes with $e, i$ or $y$ after it, it sounds as [s], like in ceiling, city (Qiang \& Xu, 2006). It is necessary for these teachers to know the rules of sound change and word syllabification. 
Table 1. Names/sounds of 26 letters

\begin{tabular}{lllllllll}
\hline Letter & Name & Sound & Letter & Name & Sound & Letter & Name & Sound \\
\hline $\mathrm{Aa}$ & {$[\mathrm{ei}]$} & {$[\mathfrak{e}]$} & $\mathrm{Bb}$ & {$[\mathrm{bi}:]$} & {$[\mathrm{b}]$} & $\mathrm{Cc}$ & {$[\mathrm{si}:]$} & {$[\mathrm{k}]$} \\
$\mathrm{Dd}$ & {$[\mathrm{di}:]$} & {$[\mathrm{d}]$} & $\mathrm{Ee}$ & {$[\mathrm{i}:]$} & {$[\mathrm{e}]$} & $\mathrm{Ff}$ & {$[\mathrm{ef}]$} & {$[\mathrm{f}]$} \\
$\mathrm{Gg}$ & {$[\mathrm{d} z \mathrm{i}:]$} & {$[\mathrm{g}]$} & $\mathrm{Hh}$ & {$[\mathrm{eit}]$} & {$[\mathrm{h}]$} & $\mathrm{Ii}$ & {$[\mathrm{ai}]$} & {$[\mathrm{i}]$} \\
$\mathrm{Jj}$ & $[\mathrm{d}] \mathrm{ji}]$ & {$[\mathrm{d}]$} & $\mathrm{Kk}$ & {$[\mathrm{kei}]$} & {$[\mathrm{k}]$} & $\mathrm{Ll}$ & {$[\mathrm{el}]$} & {$[1]$} \\
$\mathrm{Mm}$ & {$[\mathrm{em}]$} & {$[\mathrm{m}]$} & $\mathrm{Nn}$ & {$[\mathrm{en}]$} & {$[\mathrm{n}]$} & $\mathrm{Oo}$ & {$[$ $]$} & {$[\mathrm{j}]$} \\
$\mathrm{Pp}$ & {$[\mathrm{pi}:]$} & {$[\mathrm{p}]$} & $\mathrm{Qq}$ & {$[\mathrm{kju}:]$} & {$[\mathrm{kw}]$} & $\mathrm{Rr}$ & {$[\mathrm{a}:]$} & {$[\mathrm{r}]$} \\
$\mathrm{Ss}$ & {$[\mathrm{es}]$} & {$[\mathrm{s}]$} & $\mathrm{Tt}$ & {$[\mathrm{ti}]$} & {$[\mathrm{t}]$} & $\mathrm{Uu}$ & {$[\mathrm{ju}:]$} & {$[\Lambda]$} \\
$\mathrm{V}$ & {$[\mathrm{vi}:]$} & {$[\mathrm{v}]$} & $\mathrm{Ww}$ & {$[\mathrm{d} \Lambda \mathrm{blju}]$} & {$[\mathrm{w}]$} & $\mathrm{Xx}$ & {$[\mathrm{eks}]$} & {$[\mathrm{ks}]$} \\
$\mathrm{Yy}$ & {$[\mathrm{wai}]$} & {$[\mathrm{j}]$} & $\mathrm{Zz}$ & {$[\mathrm{zed}]$} & {$[\mathrm{z}]$} & & & \\
\hline
\end{tabular}

Table 2. Eight types of multiple phonograms

\begin{tabular}{|c|c|c|}
\hline Types & Multiple Phonograms & Examples \\
\hline Vowel Y & & my, happy, yes \\
\hline $\begin{array}{l}\text { Short Vowel } \\
\text { (letter-sound) }\end{array}$ & A, E, I, O, U & bạd, bedd, bigg, dog, bus \\
\hline Long Vowel & (1)A, E, I, O, U & cake, eve, bike, home, cute; rain, day; sea, bee; lie, \\
\hline $\begin{array}{l}(\text { see } \\
\text { (letter-name) }\end{array}$ & $\begin{array}{l}\text { (2)Final E: a_e, e_e, i_e, o_e, u_e } \\
\text { (3)ai, ay; ea, ee; ie, igh; oa, oe, } \\
\text { ow; ui, ue, ew }\end{array}$ & right; road, toe, 1 low; suit, cue, new \\
\hline $\begin{array}{l}\text { R-controlled } \\
\text { Vowel }\end{array}$ & ar, er, ir, or, ur, ear, air & car, mother, bird, color, purple, hear, hair \\
\hline Diphthong & oi, oy, ou, ow & point, boy, house, cow \\
\hline Digraph & al, au, aw, oo, sh, ch, th, ph, gh & $\begin{array}{l}\text { talk, because, saw, book, fish, chair, three, physics, } \\
\text { laugh }\end{array}$ \\
\hline $\begin{array}{l}\text { Consonant } \\
\text { Blends }\end{array}$ & $\begin{array}{l}\text { bl, br, cl, cr, fl, fr, gl, gr, pl, pr, sc, } \\
\text { sk, sl, sm, sn, sp, st, sw, tr, dr, scr, } \\
\text { spr, str, shr, thr }\end{array}$ & 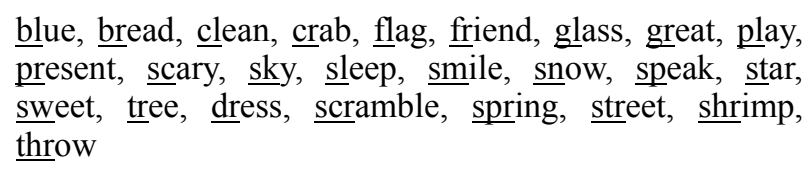 \\
\hline Silent Letter & $\mathrm{ck}, \mathrm{wr}, \mathrm{kn}, \mathrm{mb}, \mathrm{tch}, \mathrm{qu}, \mathrm{wh}$ & back, write, know, climb, watch, quiet, what/who \\
\hline
\end{tabular}

Table 3. Spelling rules

\begin{tabular}{|c|c|}
\hline Spelling rules & Examples \\
\hline When vowel $y$ is at the end of the word, it sounds out as the name of $I$. & by, sky, cry, fly, fry, my \\
\hline $\begin{array}{l}\text { When there are two or more vowels, and } y \text { is at the end of the word, it sounds out } \\
\text { as the sound of } I \text {. }\end{array}$ & lady, body, happy, daddy \\
\hline When $y$ is at the beginning, it sounds out as its letter-sound. & you, your, yes, yellow \\
\hline $\begin{array}{l}\text { When a word has only one vowel, and ends with a consonant, the vowel usually } \\
\text { sounds out as letter-sound. }\end{array}$ & 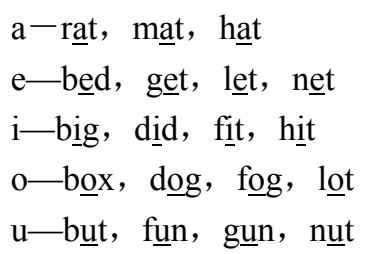 \\
\hline When the word has only one syllable, the vowel usually sounds as short vowel. & bạt, vett, sitt, côt \\
\hline $\begin{array}{l}\text { When two vowels make a syllable together, the first vowel usually sounds out as } \\
\text { long vowel, while the second is silent. }\end{array}$ & $\begin{array}{l}\text { bean, boat } \\
\text { chief (exception) }\end{array}$ \\
\hline When a syllable ends with only one vowel, it sounds out as long vowel. & he, she, be \\
\hline
\end{tabular}


Moreover, other phonics-oriented knowledge was included in this program.

Oral English skills. In order to help EFL teachers use phonics strategy to identify new words, sentences and paragraphs, the training contents included words, expressions, topics and teacher talk in New Standard English, the textbook used among local schools.

English teaching skills. This section included such modules as teaching tools, stick figures, nursery rhymes, songs, and games. Take English teaching games for example. EFL teachers need to understand and master the principle of using games, and then design or adapt games according to the teaching contents. In the end, they learn how to apply different types of games to their teaching.

English teaching philosophy. This section was conducted in the form of lectures with a focus on the practical implication of different concepts. It helped EFL teachers understand national English teaching standard, English teaching theories, second language acquisition, inter-language theory, TPR theory, English immersion theory, task-based teaching and classroom teaching strategies.

English textbook teaching. Based on the EFL teachers' understanding of New Standard English, this section guided them to analyze the principles, structure and content system of the textbook, with an emphasis on how to make teaching plans.

\subsubsection{Phonics-oriented Training-of-trainers Program}

To meet the local need of large quantity of EFL teachers, the purpose of this program was to train EFL teachers to be qualified trainers. A group of 21 EFL teachers with an English diploma were recruited: 6 from Ningxia University and Ningxia Teacher Training Center, 15 from the teaching and research section in the county Education Bureau and teacher training school (The program proposal, 2005).

Compared with attendees in the Training-of-Teachers program, they expected more from the new phonics teaching method. As they stated in their journals, "Though I tried to change my way of teaching, I failed to get any fruitful results. So I'm more anxious about English teaching method." "I desire to learn a more effective method to help students learn better." Therefore, based on their needs, the training covered phonics teaching, basic English courses, and teaching method courses. For phonics, it was expected that they would master the spelling rules and get improved in pronunciation, fluency and coherency. The other sections focused on developing the qualities of these prospective trainers: designing training plan, mastering training skills, creating a positive training environment, etc.

Based on their strengths shown above, they were assigned different training tasks so that they could conduct local training as a team. A series of assessments were organized after each course, including oral test, written test, trial teaching and descriptive assessment to judge whether they could be qualified trainers. At the end of this program, 15 attendees were confirmed as qualified trainers, among which 5 were verified as trainers at provincial level.

\subsubsection{In-service Professional Support System}

Having completed the training, the EFL teachers continued to teach in their respective rural schools. Yet, they met other difficulties in teaching practice. On one hand, there were no opportunities for them to practice oral English with colleagues given the fact that there was only one English teacher in most rural schools. On the other, the teaching resources such as workbooks, cards, CDs and course-wares were in desperate need.

Given this situation, a professional support system was constructed involving expert group (university researchers and trainers), English teaching specialists, directors of education bureaus, school headmasters or teaching directors, core EFL teachers and ordinary EFL teachers (see Figure 1). In this support system, core EFL teachers played a key role in connecting all the actors. Specifically, a learning community of 5 to 10 people was built up in central school districts. This community carried out face-to-face teaching-research activities once a week convened by core teachers. These activities included teaching plan designing, classroom observation, comments and feedbacks, etc. Since all the participants were encouraged to exchange ideas in English with supervision from teaching specialists sometimes, an English learning environment was created in which they felt a sense of belonging professionally. 


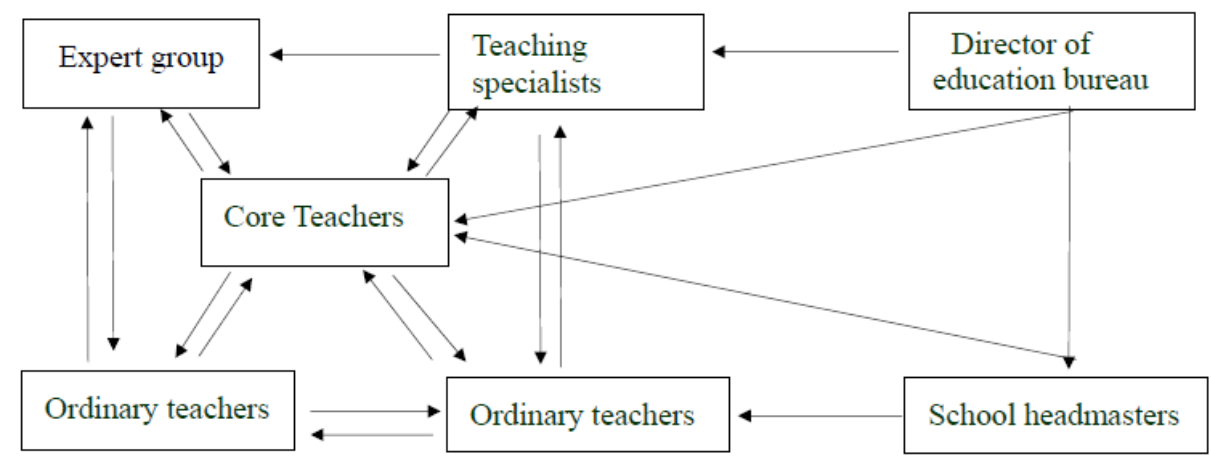

Figure 1. Participants of the support system

Aside from face-to-face communication, EFL teachers could turn to virtual communication with professionals online http://www.mtevideo.cn (Ford Foundation Project Phonics) (see Note 2). Logging in with real names, they could have access to the regularly-updated teaching resources including videos, courseware, songs, games etc. They could also share their ideas and post their problems in the forum. Taken together, as can be seen in this system, core teachers were in the center, helping ordinary EFL teachers through the connection with all the other actors by all means: e-mail, telephone, QQ social software, etc. With this support system, EFL teachers could reduce frustration when they met difficulties in teaching practice and professional development.

\section{Methods}

\subsection{Participants}

The participants in this study included pupils and primary EFL teachers. The pupils were from three experimental classes (with trained teachers) and three ordinary classes (with untrained teachers) in a primary school in Ningxia. The three ordinary classes formed the control group with 125 students and the experimental group had 104 students.

\subsection{Data Collection}

After the implementation of the training programs, 505 EFL teachers and prospective trainers resumed teaching at primary schools. To evaluate the ability of these trained EFL teachers and the effect of the training program, data were collected through classroom observations, interviews and student tests.

Firstly, classroom observation was conducted during eight EFL teachers' English lessons. Besides silent observation, participated observation was also conducted in which the researcher worked not only as an observer but also as a participant in the activities of the observed. Overall, the researchers observed the EFL teachers through their training class (to observe the EFL teachers' attitude and receptive capability), other trainers' workshops, and the EFL teachers' group demo teaching (to examine how they applied phonics knowledge to the teaching practice).

Secondly, a test was organized to evaluate students' English language skills and phonics strategies. Examination questions from Cambridge Young Learners English designed by Cambridge University Board of Examination for non-native English learners were adopted.

Furthermore, semi-structured interviews were made after training to gather information in depth. The interviewees were 15 EFL teachers. The guiding questions in the interview included: 1) What do you think of the differences between phonics-oriented training and other previous training you received in terms of their effectiveness? 2)What are the changes in English teaching after the training? 3)What are the barriers in implementing phonics-oriented classroom teaching?

\section{Results}

\subsection{Systematic Phonics-oriented Training Was Effective for EFL Teachers' Pronunciation, Vocabulary and Teaching Philosophy}

Phonics, as the core of the current training programs, was borrowed from North America where it is used as an approach to teach young beginners (age 5-8). Was it useful for training adult English teachers or prospective trainers in China? Trainees' interviews showed positive effect.

Overall, in the pre-test before training, the EFL teachers' pronunciation had huge flaws. Now their pronunciation 
became more accurate and coherent, and their vocabulary was greatly enlarged through phonics. As they could speak more fluently and learn more words, their attitude of learning changed from frustration to excitement. In the interviews, they stated that "Phonics allowed us to be aware of the connection between sound and written form, which reduced the difficulties to sound out and spell new words." (Kang, 2012, p. 287) They also stated that the vocabulary they learned with phonics method was much larger than what they learned in previous years. More importantly, most of these words were stored in long term memory. (Kang, 2012, p. 291) Through learning letter-sound relationships as they relate to literacy, these EFL teachers learned to identify and build an internal database of known words (Sprague, 2008).

EFL teachers also benefited from the philosophy of teaching phonics. They regarded phonics as a brand-new teaching method, which was quite exciting in that the spelling rules were not learned directly but through games, nursery, story and body language (Kang, 2012, p. 287). Moreover, Phonics stimulated their curiosity by combining music, painting and dance (Kang, 2012, p. 287).

\subsection{EFL Teachers' Professionalism Was Greatly Improved through Phonics-oriented Training}

Through phonics-oriented training, EFL teachers also learned many teaching skills and their applications in more interactive activities: adapting songs, stories, games, making all kinds of cards and hand puppets. As Zhuangang teachers, they also transferred their previous teaching skills to English teaching.

In classroom observations, the researchers found it amazing that the EFL teachers taught children in commendable English, given that they weren't able to pronounce 26 letters correctly before training. Compared with untrained teachers, their teaching was more active and vivid with songs, rhythms, acting, pictures and games which easily aroused students' interest. Moreover, their ability to organize interactive classroom activities was well developed. They utilized some useful English expressions to attract students instead of using Chinese, greatly enriching English language input.

The interviews later showed that they became more professional through participating in learning community activities. They could make more professional comments on colleagues' teaching and reflect on their own by writing teaching journals.

\subsection{Students with Trained Teachers Had Better Performance in Overall English Achievement}

The result of the student test (Qiang \& Yu, 2007) showed that the average scores in experimental classes were significantly higher than those of students in ordinary classes (Table 4). Furthermore, students in experimental classes did much better in English listening, speaking, reading and words-memory (Table 5-8). Therefore, EFL teacher training through phonics is effective.

Table 4. Overall comparison

\begin{tabular}{lllllll}
\hline & N of Students & Average Score & Standard Deviation & Mean Deviation & $t$ & $p$ \\
\hline Experimental Classes & 104 & 30.62 & 11.31 & \multirow{2}{*}{11.88} & \multirow{2}{*}{8.200} & 0.000 \\
Ordinary Classes & 125 & 18.74 & 10.58 & & & \\
\hline
\end{tabular}

Table 5. Comparison of spoken English

\begin{tabular}{lllllll}
\hline & N of Students & Average Score & Standard Deviation & Mean Deviation & $t$ & $p$ \\
\hline Experimental Classes & 104 & 7.82 & 3.53 & 4.81 & \multirow{2}{*}{9.077} & 0.000 \\
Ordinary Classes & 125 & 3.01 & 4.48 & & \\
\hline
\end{tabular}

Table 6. Comparison of listening comprehension

\begin{tabular}{lllllll}
\hline & N of Students & Average Score & Standard Deviation & Mean Deviation & $t$ & $p$ \\
\hline Experimental Classes & 104 & 6.81 & 3.84 & 2.26 & \multirow{2}{*}{5.142} & 0.000 \\
Ordinary Classes & 125 & 4.54 & 2.54 & & & \\
\hline
\end{tabular}


Table 7. Comparison of reading comprehension

\begin{tabular}{lllllll}
\hline & N of Students & $\begin{array}{l}\text { Average } \\
\text { Score }\end{array}$ & $\begin{array}{l}\text { Standard } \\
\text { Deviation }\end{array}$ & Mean Deviation & $t$ & $p$ \\
\hline Experimental Classes & 104 & 10.07 & 3.01 & 2.46 & 4.870 & 0.000 \\
Ordinary Classes & 125 & 7.61 & 4.58 & & & \\
\hline
\end{tabular}

Table 8. Comparison of words-memory

\begin{tabular}{|c|c|c|c|c|c|c|}
\hline & $\begin{array}{l}\mathrm{N} \\
\text { Students }\end{array}$ & $\begin{array}{l}\text { Average } \\
\text { Score }\end{array}$ & $\begin{array}{l}\text { Standard } \\
\text { Deviation }\end{array}$ & $\begin{array}{l}\text { Mean } \\
\text { Deviation }\end{array}$ & $t$ & $p$ \\
\hline Experimental Classes & 104 & 5.92 & 4.04 & \multirow{2}{*}{2.36} & \multirow{2}{*}{4.432} & \multirow{2}{*}{0.000} \\
\hline Ordinary Classes & 125 & 3.56 & 4.00 & & & \\
\hline
\end{tabular}

\section{Discussion}

The current study explored phonics-oriented training and its effectiveness. The results showed that this training improved EFL teacher's English pronunciation, reading, and more importantly, their teaching skill which correspondingly enhanced student learning. The following parts provided detailed discussion of the effectiveness of phonics-oriented training.

\subsection{Phonics, as the Core of the Entire Training, Is a Key to Success}

In the United States and Canada, phonics training has been conducted to teach new immigrants in a second-language environment where English can be heard everywhere. However, in China, no programs have adopted phonics as a way to train adults. In this sense, it is an innovation to introduce phonics to rural China where English is never used in daily life. Here, the phonics method could be successfully implemented due to the factors below.

Firstly, phonics, with its focus on letter-sound relationship and phonics rules, meets the requirements of National English Curriculum Standard which clearly states that students who complete primary school should be able to identify words and phrases and read simple words according to spelling rules (Cao, 2017).

Secondly, in practicing oral English and understanding local student book, phonics is used to decode new words with spelling rules. As EFL teachers learn different kinds of teaching skills, they master phonics teaching strategies like word decoding, phoneme segmenting, phoneme blending and phonological awareness. As a result, they can decode all the new words in the textbook and become independent readers.

Thirdly, phonics training itself has been systematically designed by Canadian and Chinese experts to meet children's learning needs in Chinese context. Since phonics is taught not only as a teaching strategy but also as "content" within an overall teaching strategy (Sprague, 2008), the content and procedures are quite explicit for EFL teachers to understand and follow. They can easily learn what phonics is and how to teach phonics simultaneously. He (2008), for example, in her book, Research on English Phonics Teaching, generalizes some teaching strategies about phonograms learning, phoneme segment, phoneme blending and phonological awareness development. Another trainer and researcher, Liang (2010) concludes that these principles have more positive impact on phonics teaching in China: teach students letter-sound (instead of letter-name) knowledge first to develop their phonological awareness through phonics, so that the students can then combine the sound of words with their meaning and become automatic decoders. Kang\& Liang (2010), in their joint book Training Tutorial for Primary School EFL Teachers: Phonics, Methods and Teachers' Development, provides practical teaching plans and teacher talk in English for teachers or trainers to follow directly. This book also provides appropriate phonics knowledge, teaching skills and strategies for teachers to become professionals.

Moreover, some EFL teachers, guided by researchers and trainers, engaged themselves in developing phonics student book and teacher book which strengthened their understanding and application of phonics. With their contribution, Phonics for Chinese Kids (Tan \& Wu, 2010) has been published and used in primary schools. In this way, phonics is gradually recognized as quite adaptive to China context.

\subsection{The Cascade Training Model Makes the Training Effective and Sustainable}

A cascade model in which the participants are both the subjects and agents of change" (Gilpin, 1997) is designed as a means of saving time, reducing cost and producing more EFL teachers. In this cascade model, the Canadian 
and Chinese phonics experts, at the top of this cascade, train one group of well-performed EFL teachers to be trainers at provincial level, who then go on to train another group of EFL teachers to be local trainers at county level. In this way, the training benefit is "cascade" downwards to ordinary EFL teachers.

The cascade model is an optimized way in China context because it can produce more EFL teachers needed within short time. In this way, the training can benefit the whole county, expanding the range of training effect. Eventually, this model enables local educational departments and schools to conduct training independently and flexibly, increasing the number of EFL teachers.

\subsection{The Management of the Training and the Professional Support System Are Highly Efficient}

The entire training was highly efficient with actors at different levels playing significant roles.

To start with, a special committee with members from provincial and county educational department, university administrators and teaching research centers, is responsible for coordinating the whole process. Feeling great pressure from the regional government and their responsibility to provide local students equal opportunities, they support the training from all aspects: funding allocation, budget balance, selecting and managing trainees. Rigorous training rules regarding absence and test are set to guarantee EFL teachers' positive participation.

Next, the professional training team at all levels is dedicated and committed to training implementation, textbook development and evaluation. Most of them have experiences in teaching and conducting research on children, thus providing more hands-on experiences to EFL teachers. Moreover, they extend training to all-round teacher development through learning communities and online forums where problems are identified and solved to relieve EFL teachers' pressures.

More importantly, the EFL teachers themselves had strong motivation to learn. On one hand, they want to be professionals to get rid of the title of Zhuangang teachers which indicates non-professionals. On the other, they understand the huge gap in educational resources between rural and urban students, therefore generating more responsibilities to help those in disadvantageous position through their efforts.

\subsection{Future Concerns}

The current study shows that phonics instruction is not only a fast, effective mode for training rural English teachers, but also an effective English teaching method in primary schools as well. However, the implementation of phonics-oriented training is not always smooth. There's resistance from school administrators and EFL teachers themselves.

At the administrative level, some principals are reluctant to engage EFL teachers in the training program because these teachers have heavy workload. Also, some principals have doubts toward the effect of training. In some schools, EFL teachers are assigned with such a heavy workload aside from English teaching that they can't concentrate on phonics teaching.

As for the EFL teachers themselves, the previous English knowledge, especially IPA knowledge, is an obstacle for them to learn phonics. Their age, years of teaching and personal characteristics also have an impact on teaching phonics, since phonics is a learner-centered teaching strategy which encourages teachers to be more passionate, interactive and good at using games and songs to enhance student learning.

Aside from the above, class size, English teaching hours, and EFL teachers' promotion are all factors that would have a negative effect on English teaching. Anyway, the implementation of phonics training, in a certain sense, helps to overcome the difficulties for some rural schools to start up English course with qualified teachers. Still, more research needs to be done to guarantee the effect of phonics teaching.

\section{Conclusion}

Due to the fact that English teachers are in great demand in rural China, we conducted phonics-oriented training program on Zhuangang EFL teachers. Data collected from classroom observations, interviews and student tests showed that the current training and support were effective and sustainable. These findings suggest that phonics-oriented English training and instruction is an effective way to enhance English teaching and learning outcome.

\section{Acknowledgements}

This study is supported by Innovative School Project in Higher Education of Guangdong, China, (GWTP-BS-2014-14) and by MOE Research Center for Online Education, China (QTONE EDUCATION), Grant No. 2016YB154. The authors would like to thank the Ford Foundation for its support and Prof. Haiyan Qiang for her help in the current study. 


\section{References}

Cao, M. (2017). An Analysis of Phonics Teaching in Mainland China. Journal of Language Teaching and Research, 8(2), 286-290. https://doi.org/10.17507/jltr.0802.09

Chen, M. S., \& Fan, W. F. (2011). Linking the Sounds with the Spelling in Learning English Words: Using Natural Pronunciation Symbols. Foreign Languages in China, 76-81.

Gao, M. (2005). The Application of Phonics in Primary English Teaching, Journal of Basic English Education, $7(6), 62-64$.

Gilpin, A. (1997). Cascade Training: sustainability or dilution? In I. McGrath (Ed.), Learning to Train: Perspectives on the Development of Language Teacher Trainers (pp. 185-194). Hemel Hempstead: Prentice Hall.

Harris T., \& Hodges R. (1995). The Literacy Dictionary: The Vocabulary of Reading and Writing. International Reading Association. Newark, DE: IRA, 184.

He, H. (2008). A Study on Phonics Teaching Strategy. Xi'an: Shaanxi People's Education Press. 18.

Huang, Y. Z., \& Chen, W. Z. (2009). An Ecocriticism on Foreign Education in China, Foreign Language Teaching \& Research in Basic Education, (2), 17-21.

Kang, Y. Q. (2012). Research on Theory and Practice of Educational Transfer: A Case of English Phonics Approach Transfer in Rural Areas in West China (Unpublished doctoral dissertation). South China Normal University, Guangzhou.

Kang, Y. Q., \& Liang, Z. X. (2010). Training Tutorial for Primary School EFL Teachers: Phonics, Methods and Teachers' Development, Shaanxi People's Education Press.

Liang, Z. X. (2010). An Action Research on Teaching Principles of Phonics (Unpublished master thesis). South China Normal University, Guangzhou.

Lin, H. (2003). A Study on Primary English Zhuangang Teachers' Training. The Modern Education Journal, (4), 54-57.

Liu, Y. J. (2008). An Exploration on Primary English Zhuangang Teachers' Training Strategies in rural Hebei Province, Journal of Hebei Normal University (Educational Science Edition), 10(8), 67-70.

MOE (The Ministry of Education of the People's Republic of China). (2001). MOE's Guidance on Actively Promoting English Courses in Primary Schools.

MOE. (2005). http://www.moe.edu.cn/edoas/website18/98/info34698.htm

Qiang, H. Y., \& Xu, J. G. (2006). A Guidebook for English Teachers at Primary schools. Xi'an: Shaanxi People's Education Press.

Qiang, H. Y., \& Yu, K. P. (2007). Assessment Report on Speed-up English Training for Rural Elementary School Teachers -Students' Language Skills[The project assessment for Ford Foundation].

Qiang, H. Y., \& Xu, J. G. (2007). Final Report of the project of Speed-up English Training for Rural Elementary School Teachers [The project report for Ford Foundation].

Qiang, H. Y. (2005). Speed-up English Training for Rural Elementary School Teachers [The project proposal for Ford Foundation].

Sprague, C. (2008). Phonics. EBSCO Research Starters, 1-7.

Tan, W. M. (2011). Problems and Solutions of Primary English Zhuangang Teachers in Guangdong Province, Foreign Language Teaching Schools (Primary School Edition), (3), 6-9.

Tan, W. M., \& Wu, S. H. (2010). Phonics for Chinese Kids. Yinchuan: Sunshine Press.

Wang, P. (2013). Perspectives on English Teacher Development in Rural Primary Schools in China. Journal of Pedagogy, 2, 208-219.

Wu, Z. M. (2005). Pre-service EFL Teacher Education in Mainland China: Case Studies of BA/TEFL Curriculum Development. Doctoral Dissertation, The Chinese University of Hong Kong.

Xie, X. D. (2007). A Study on Primary English Zhuangang Teachers' Training Practice. Jiangsu Education Research, (12), 24-25.

Xiong, T., \& Xiong, X. Z. (2017). The EFL Teachers' Perceptions of Teacher Identity: A Survey of Zhuangang 
and Non-zhuangang Primary School Teachers in China, English Language Teaching, 10(4), 100-110. http://doi.org/10.5539/elt.v10n4p100

You, H. Y. (2016). A Study on the Construction of Regional Professional Community and New Teacher Development Modes Based on Rural Primary English Teachers' Training, Journal of Curriculum and Instruction, (5), 91-93.

Zhang, X. Z. (2004). A Study on Primary English Zhuangang Teachers' Training Mode, Journal of Ningbo University (Educational Science Edition), 26(5), 71-73.

Zheng, X. F. (2006). Development of Foreign Language Education in Chinese School, Journal of Chongqing Institute of Technology, 20(4), 169-171.

\section{Notes}

Note 1. In phonics instruction, Aa, Ee, Ii, Oo and Uu are called vowel letters. When they make sound as [æ] [e] [i] [ग] [ $\Lambda$, they are called short vowel. When they sound as [ei] [i:] [ai] [əu] [ju:], they are called long vowel.

Note 2. The website was closed four years later after the training when it fulfilled its responsibilities to assist EFL teachers with their professional development. All the documents on it have been stored in computer hard drive by the researchers.

\section{Copyrights}

Copyright for this article is retained by the author(s), with first publication rights granted to the journal.

This is an open-access article distributed under the terms and conditions of the Creative Commons Attribution license (http://creativecommons.org/licenses/by/4.0/). 